\title{
Analyzing the Relationship Between Investment and Financial Performance of Industrial Companies Listed on the Amman Financial Market During the Period 2005-2018
}

\author{
Dr. Ateyah Mohammad Alawneh \\ Tafila Technical University, College of Business, AT-Tafila, Jordan
}

\begin{abstract}
The study aims to analyze the effect of long- and short-term investment on the financial performance (return on equity, return on assets, earning per share, and net profit after tax) for industrial companies listed on the Amman Financial Market during the period 2005-2018. The study relied on the combined financial data of industrial companies in the Amman Financial Market to test the hypotheses of the study and on the method of multiple regression analysis using the (E-views) program. The standard analysis showed a significant negative relationship between long-term investment and return on equity, return on assets, return per share, and net profit after tax for industrial companies in Jordan. The study also found a negative relationship between short-term investment and net profit and a weak negative relationship between short-term investment and return per share. However, no significant relationship is found between short-term investment and return on equity and return on assets. The study also analyzed the co-integration between the study variables using the Johansson test for co-integration, where the analysis showed the existence of a long-term equilibrium relationship between the study variables as these variables do not move away from each other so that they exhibit similar behavior in the long term. One of the most important recommendations of the study is that investment managers in industrial companies must consider feasibility studies for proposed investment projects.
\end{abstract}

Keywords: financial performance, return on equity, return on assets, earnings per share and net profit after tax, long-term investment, short-term investment

DOI: $10.7176 / \mathrm{JEP} / 11-24-11$

Publication date: December $31^{\text {st }} 2020$

\section{1- Introduction}

Investment has elicited considerable attention from companies and those in charge of determining investment decisions. Investment is one of the most important decisions in companies because it leads to exorbitant costs that must be matched by a return commensurate with the cost.

Companies make new investments to increase financial performance, such as return on equity or return on assets. However, investments may often face unfavorable economic conditions, such as economic depression, inflation, and competition, leading to a negative impact on the financial performance of industrial companies, such as return on equity and return on assets. Investments face joint risks when establishing a new investment project, possibly leading to large losses as a result of the company replacing variable costs with fixed costs. Given that the company incurs high costs at the same time, an economic depression might lead to a decrease in the company's sales, negatively affecting the financial performance of industrial companies. Therefore, the new investment decision must consider the surrounding economic conditions due to the difficulty of retreating from investment in the event of implementation because its costs are exorbitant.

Furthermore, short-term investments, which represent investments in short-term securities to help companies obtain a return from these investments, lead to increased financial performance. However, industrial companies may face considerable difficulties in these investments, negatively affecting financial performance. Such effects include interest rate risks that negatively affect the financial performance of industrial companies as a result of interest rate fluctuations in addition to their negative effects on raising the cost of investment for industrial companies.

Therefore, this study analyzed the relationship between investment (long- and short-term) as independent variables on financial performance such as return on equity, return on assets, return on, share and net profit for industrial companies listed on the Amman Financial Market to help investment managers and investment decisionmakers. In industrial companies, the impact of long-term and short-term investment on financial performance is recognized because the company is interested in new investments in the hope of increasing the financial performance and having a positive effect in increasing the profit rates of industrial companies.

The study will be divided into four parts. The first part introduces the study. The second part addresses the theoretical framework and previous studies. The third part presents hypothesises test and co- integration test for the study models. The fourth part provides the results and recommendations. 


\section{1- Study Problem.}

The study problem comes from the realistic consideration that investment in industrial companies is one of the most important topics in which companies are interested. They expand the existing investment by building new projects to increase the company's profitability. Therefore, the problem of the study is represented by the following question.

1- What is the effect of long -term investment on the return on equity of industrial companies listed on the Amman Stock Exchange?

2- What is the effect of short-term investment on the return on equity for industrial companies listed on the Amman Stock Exchange?

3- What is the effect of long-term investment on the return on assets of industrial companies listed on the Amman Stock Exchange?

4- What is the effect of short-term investment on the return on assets of industrial companies listed on the Amman Stock Exchange?

5- What is the effect of long-term investment on earnings per share for industrial companies listed on the Amman Stock Exchange?

6- What is the effect of short-term investment on earnings per share for industrial companies listed on the Amman Stock Exchange?

7- What is the effect of long-term investment on the net profit after tax of industrial companies listed on the Amman Stock Exchange?

8- What is the effect of short-term investment on the net profit after tax of industrial companies listed on the Amman Stock Exchange?

\section{2- Importance of the study}

The study sheds light on one of the important and main topics in industrial companies that are of interest to investment managers, helping them to identify the effect of long- and short-term investment on financial performance and the interests of the company's owners and shareholders. Industrial companies, when they make investments, seek the profit that is reflected in the financial performance. Therefore, the study is important for the continuation, survival, and growth of companies because this study is concerned with investment and the financial performance of companies such as return on equity, return on assets, earnings per share, and net profit after tax, which all employees of the company also care about. This study is also useful in determining the nature of the relationship and the co- integration relationship between short- and long-term investment and financial performance, helping managers understand investment behavior. Furthermore, the study obtains accurate results to help investment decision-makers in light of the economic conditions that industrial companies are experiencing.

\section{3- Objectives of the study}

The objective of the study is to explain the effect of long-term investment (capital spending) and short-term investment on the return on equity, return on assets, earning per share and net profit after tax of industrial companies listed on the Amman Stock Exchange.

\section{4- Hypotheses of the study}

1 - No statistically significant positive relationship at $(\alpha \geq 0.05)$ is found between long-term investment and return on equity.

2- No statistically significant positive relationship at $(\alpha \geq 0.05)$ is found between short-term investment and return on equity.

3- No statistically significant positive relationship at $(\alpha \geq 0.05)$ is found between long-term investment and return on assets

4- No statistically significant positive relationship at $(\alpha \geq 0.05)$ is found between short-term investment and return on assets

5- No statistically significant positive relationship at $(\alpha \geq 0.05)$ is found between long-term investment and earnings per share.

6- No statistically significant positive relationship at $(\alpha \geq 0.05)$ is found between short-term investment and earnings per share

7- No statistically significant positive relationship at $(\alpha \geq 0.05)$ is found between long-term investment and net profit after tax

8- No statistically significant positive relationship at $(\alpha \geq 0.05)$ is found between short-term investment and net profit after tax

\section{5- Study methodology:}

This study will adopt the descriptive and analytical method. The study data will be obtained through the Amman 
Financial Market website. The study sample includes all industrial companies listed in the Amman Financial Market by taking the accumulated financial data. The study variables will be analyzed using multiple linear regression to obtain the results The study will also analyze the Johansen Co-integration test of the study models. .

\section{6- Models of the study}
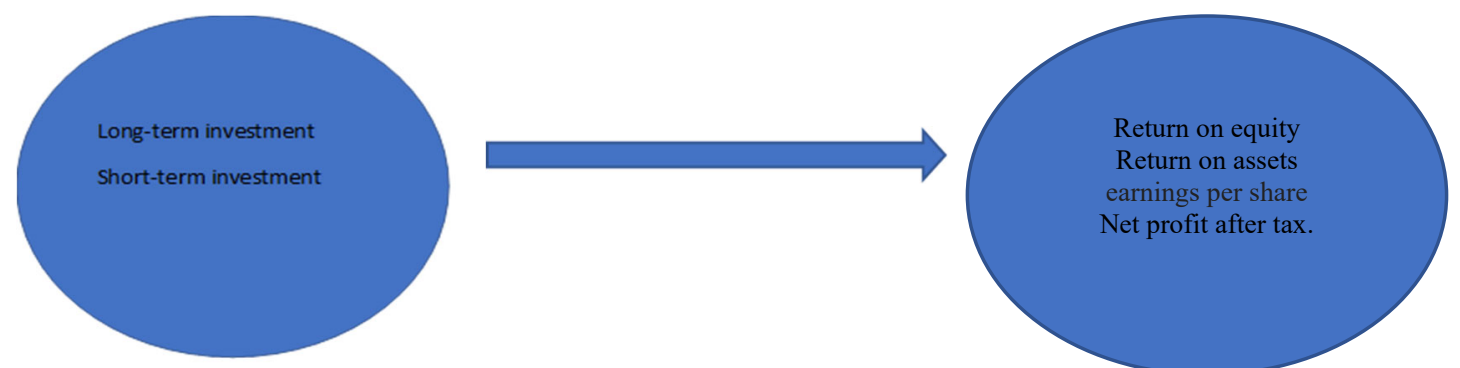

In order to test the hypotheses of the study, multiple regression analysis using E-views w1Il be used to study the effect of independent variables. Long-term investment and short-term investing will be tested on return on equity, return on assets, earnings per share and net profit, four standard models for this purpose. As follows Model 1: The impact of long-term and short-term investment on return on equity through the following model.

$\mathrm{ROEI}=\alpha+\beta 1 \mathrm{LINI}+\beta 2 \mathrm{INSI}+\mathrm{E}$

Where

ROEI: the rate of return on return on equity for industrial companies listed on the Amman Stock

Exchange during the study period

$\alpha$ : the constant in the regression equation

LINI: The value of long-term investment is in one million Jordanian dinars for industrial companies listed on the Amman Stock Exchange during the study period

NISI: The value of short investment in million Jordanian dinars for the industrial companies listed on the Amman Stock Exchange during the study period

E: standard error

$\beta 1, \beta 2:$ the regression parameters to be estimated

Model 2: the effect of long-term and short-term investment on the return on assets through the following model.

$\mathrm{ROAI}=\alpha+\beta 1 \mathrm{LINI}+\beta 2 \mathrm{INSI}+\mathrm{E}$

Where

ROAI: the return on assets for the industrial companies listed on the Amman Stock Exchange during the study period

Model 3: The effect of long-term and short-term investment on Earnings per share through the following model.

EPSI $=\alpha+\beta 1$ LINI $+\beta 2$ INSI $+\mathbf{E}$

EPSI: Earnings per share for industrial companies listed on the Amman Stock Exchange during the study period

Model 4: The effect of long-term and short-term investment on the net profit after tax of industrial

companies listed on the Amman Stock Exchange during the study period through the following form.

NPI $=\alpha+\beta 1$ LINI $+\beta 2 I N S I+E$

where

NPI: Net profit after tax for industrial companies listed on the Amman Stock Exchange during the study period.

\section{2- Previous studies and theoretical Framework.}

\section{1- Previous studies}

Numerous previous studies that have focused on the impact of investment is long and short term on some variables of the study, including them.

Study of Geoff Warren, 2014. The study presents the literature related to long- and short-term investment and the aspects with which investors are concerned when making an investment decision. The study shows, by reviewing the literature on the subject, that investors are more interested in the long-term return generated from investment and future cash flows than in changing stock prices in the near term, thereby contributing to directing investors toward long-term investment in exchange for short-term investment.

Study of Peter Weil, 1992. The study aims to clarify the effect of investment in information technology on 
the performance of companies. A total of 33 companies were taken from the manufacturing sector. Questions were directed to executives in the companies and production managers regarding the performance of this company. The study focused on the impact of information technology on the return on assets and the productivity of workers. The growth of sales and the results of the study showed a positive effect of investing in technology on the performance of companies in the industrial sector. However, this effect becomes neutral in the long term and its effect is on poorly performing companies in the short term. The study also shows that the advantage of modern technology in companies is lacking whenever the technology becomes popular.

Study of Hasan Subhi Hasan Hussein Alabass, 2019. The study aims to clarify the effect of investor behavior in companies on financial performance. Data from 2010 to 2015 were taken to 500 companies on the Pakistan Stock Exchange. The analysis showed a positive effect on investor behavior on the financial performance of companies. The study recommends that investment policies should be prepared accordingly.

Study of Chashmi NA and Fadaee M, 2016. The study aims to clarify the effect of financial performance and growth opportunities on the failure and success of the company. A sample was taken from 115 companies in the Tehran Stock Exchange. The study used the financial performance ratios (including earnings per share, return on equity, return on assets, and growth opportunities) on the success and failure of the company as a dependent variable. The study relied on Pearson correlation analysis and multiple regression analysis. The standard analysis showed a significant relationship between return on assets and earnings per share and the success and failure of the company. No relationship was found between the rate of return on equity and the failure and success of the company. The analysis also showed that growth opportunities did not affect the failure and success of the company.

Study of Hadi Santoso, 2019. The study aims to clarify the relationship between investment decisions. The study used a sample of consumer goods institutions listed on the Indonesia Stock Exchange during the period 2010-2017. The study found that long-term investment decisions affect financial performance (return on investment) as an indicator of return in this study but also found that long-term investment decisions do not affect the value of the company.

Study of Martijn Cremers, Ankur Pareek, and Zacharias Sautner, 2017. The study shows that increasing shortterm investment leads companies to reduce long-term investment and investment in research and development, leading to an increase in earnings per share. This strategy is for a temporary period, not long-term.

Study of Anas Ali Al-Qudah and Mohammad Abdel Mohsen Al-Afeef, 2015. The study presents the relationship between investments in current assets and its effects on the profitability and liquidity of industrial companies listed in the Amman Financial Market. The analysis showed a relationship between investment in current assets, profitability, and liquidity. The study recommended the necessity of a balance in investment between current and fixed assets so that the ratio is moderate and considers the return and risk.

Study of Baciu and Brezeanu Petre, 2018. The study aims to clarify the relationship between the financial structure and its effect on the return on return on equity for the auto parts trade in Romania. The study used several financial ratios such as the ratio of return on equity to assets, turnover/assets, and debt from credit institutions on short-term plus long-term/assets. The analysis showed that the financial structure does not significantly affect the return on equity.

Study of Muhammad Samih Tayfour, 2011. The study aims to clarify the effect of capital spending on the financial and operational performance of the Jordanian pharmaceutical industry. The analysis showed no relationship between capital spending and the financial and operational performance of Jordanian pharmaceutical companies. The important recommendations of the study include the necessity of following modern methods in evaluating capital spending and training the authorities responsible for capital spending on long-term asset management skills.

Study of Pu Shen, 2005. The study shows that long-term investment was achieving negative losses, whether in stocks or bonds. The study also reveals that the investor who owns a 10-year stock contract achieves a positive return and that stocks, in general, performed better than did bonds over a 20 -year period.

Study of Abdkader Ahmad Hussen, 2017. The study aims to clarify the relationship between investment and the financial performance of commercial banks in Kenya. The analysis showed the existence of a negative statistically significant relationship between investment in government securities and return on assets. The analysis also showed a negative statistically significant relationship between the risk of facilities and the return on assets, while the relationship is positive between investment in bonds and return on assets. One of the most important recommendations of the study was that banks should focus on investing in stocks and that the need to manage the capital and liquidity ratios to enhance the financial performance of banks.

Study of Almas Heshmati and Hans Loof, 2008. The study aims to clarify the causal relationship between investment in research and development, physical capital, and financial performance. Financial performance indicators, such as sales, profits, and the added value of Swedish companies during the period (1992-2000) were taken, and the results of the study were tested by applying multivariate self-regression. The study found some bidirectional causal relationships between the variables but found heterogeneity in corporate investments.

Study of Crispus Ndungu Karanja, 2012. The study aims to analyze the relationship between investment 
decisions and the financial performance of small and medium enterprises in Limuru City, Kenya. The results of the analysis showed a weak relationship between investment and financial performance in companies. However, a sample was taken by distributing the questionnaire, the analysis showed that approximately $55 \%$ of the respondents indicated a positive relationship between investment and financial performance due to improved service delivery and improved market conditions. Approximately $30 \%$ indicated a significant decrease in financial performance due to increased costs.

\section{2- Features of the current study}

Some previous studies examined the relationship between investment and some financial performance indicators. However, this study relied on finding the effect and the co- integration for models of the study during 2001-2019. The dependent variables were used as an indicator of financial performance (rate of return on assets, rate of return on equity, net profit, and return on share), which were not used in previous studies. This study, to the best of the researcher's knowledge, is one of the rare studies that uses the investment and financial performance of industrial companies in Jordan.

\section{3- theoretical Framework}

\subsection{1- Long-term and short-term investment.}

Long-term investment: This means the firm's decision to invest the money in an ideal way in long-term activities through which it is expected to have a line of cash returns for several years. For example, the decision to buy a machine is a capital spending decision because it extends for a long time, and one of the advantages of long-term investing is that the investment decision is only an exchange of money at present for expected returns in the future, meaning the exchange of the initial cost with expected cash flows, such as expected returns in the future over a number of years. Long-term investment in industrial companies is a real investment and capital spending on real production lines and projects; such investment differs from long-term investment in the financial or insurance sectors. Therefore, we find that this important investment includes long-term results and affects risk indicators in the company and differs from investment in assets. Short-term trading determines the direction and growth of the company. Therefore, the wrong investment decisions lead to disasters that affect the existence of the company itself because the expansion of inappropriate long-term investment leads to a significant increase in the operating expenses of the company or facility and thus leads to a decrease in the company's financial performance. By contrast, the lack of necessary and long-term investments renders the company's competitiveness limited, exposing it to the possibility of realizing its losses (Shukiri Nouri et al., 2012).

Inappropriate investment brings losses to the company, and therefore its relationship with the financial performance of the company will be negative and vice versa, the thoughtful and appropriate investment for the company achieves positive results on the financial performance of the company. The lack of investment has a negative effect on the company as well, so long-term investment requires large amounts. Therefore, the company must plan for long-term investments in addition to the difficulty of returning from investment, especially when entering into large and long-term investment projects. The prediction of the future cash flows of the investment is related to many economic, political, social, or technological events.

Long-term investments are exposed to many risks that lead to losses in companies related to systemic risks such as inflation and economic depression, or even company risks or non-systemic risks, which include industry or competition risks. The company is exposed to common risks, such as operational risks and financial leverage risks, possibly due to such investment, especially in cases of economic depression that leads to a decrease in companies' sales, leading to a decline in the financial performance of these companies.

In industrial companies, investments in stocks for a long time may be long-term investments, but as industrial companies, they focus on investing in real assets and keep short-term financial investments in industrial companies for liquidity and the speed of converting them into cash in case of need where investing stocks in the short term to achieve a quick return is called a short-term investment (Al Shugairi and et al . 2016, pp 112-115).

\subsection{2- dependent variables of the study.}

- Return on equity $(\mathrm{ROEI})=$ the net profit attributable to the company's shareholders on equity

- Return on assets (ROAI) $=$ the net profit after tax + interest expense on total assets.

- Earnings per share (EPSI) $=$ Net profit attributable to the company's shareholders on

Number of shares subscribed.

- Net profit (NPI)=revenue - expenses - tax) (Amman Financial Market, Companies Directory, Consolidated Financial Statements online https://www.ase.com.jo/ar/history?history_category=65,)

\subsection{3- Relationship between corporate investment and financial performance.}

Some studies have found a positive relationship between investment and financial performance as a study Hasan Subhi Hasan and Hussein Alabass (2019), also study of Hadi Santoso,2019. However, some studies showed no relationship between real long-term investment and financial performance, such as Muhammad Samih Tayfour (2011). Other showed a negative relationship between long-term investment and financial performances such as 
$\mathrm{Pu}$ Shen(2005), a negative relationship between short-term investment and financial performance such as Abdkader ahmad Hussen (2017), and a weak relationship between investment and financial performance such as Crispus Ndungu Karanja( 2012). The reason for these different results is the nature of the relationship between investment and financial performance and the economic situation in the country and the suitability of the state's industrial investment, which varies from country to country from the scientific side.

The negative relationship between investment and financial performance may be due to what is explained the school of surplus investment, like Clark and Harrod, the problem is in the volatility of investment spending governed by the accelerator principle and the resulting real imbalances in production structures due to the high sensitivity of the productive asset industry. (Abdul-Jabbar Al-Sebhani, $\underline{\text { https://al- }}$ sabhany.com/index.php/articles/financial-crisis).

\subsection{4- Descriptive statistics.}

Table (1) shows that the highest value of long-term investment was $(646,731,195)$ JD. The lowest value during the study period was $(2,095,265) \mathrm{JD}$, with an average value of $(458,957,694) \mathrm{JD}$. Notably, the value of long-term investment in industrial companies in Jordan has increased due to the nature of the industrial sector, which is a productive sector that needs real long-term investment to enhance the company's growth in the market.

Table (1) also indicates that the highest value of short-term investment was $(80,474,241) \mathrm{JD}$, and the lowest value (5905241) JD during the study period, at an average value of $(20,952,657)$ JD. Notably, value of short-term investment in industrial companies in Jordan may decrease due to the nature of the industrial sector because it is a productive sector that does not focus on short-term investment Thus, the investment may be short-term for liquidity purposes or to meet the company's short-term needs.

Table No. (1) Descriptive statistics

\begin{tabular}{|l|l|l|}
\hline Descriptive statistics & LINI & INSI \\
\hline Mean & $458,957,694$ & 20952657 \\
\hline Maximum & 646731195 & 80474241 \\
\hline Minimum & 20952657 & 5905241 \\
\hline
\end{tabular}

Source: Prepared by the researcher using the E-views program based on the study data in Appendix No. (1).

Table (2) shows that the highest percentage of return on equity was $(26 \%)$, and the lowest percentage was $(1.14 \%)$. The average was $(10.38 \%)$. The highest percentage of ROA was $(17.82 \%$, and the lowest percentage was $(0.85 \%)$, with an average of $(7.29 \%)$. Table (2) shows that the highest percentage of EPS was $(0.25 \%)$, and the lowest percentage was $(0.03 \%)$, with an average of $(0.63 \%)$. Table (1) also shows that the highest value of NP was $(578,996,005) \mathrm{JD}$ and the lowest value was $(32,311,523) \mathrm{JD}$, with an average value of $(242,997,519) \mathrm{JD}$.

Table No. (2) Descriptive statistics

\begin{tabular}{|l|l|l|l|l|}
\hline Descriptive statistics & ROEI & ROAI & EPSI & NPI \\
\hline Mean & 10.38284 & 7.291119 & 0.250638 & $242,997,519$ \\
\hline Maximum & 26.63478 & 17.82671 & 0.639866 & $578,996,005$ \\
\hline Minimum & 1.149329 & 0.853982 & 0.033268 & 32311523 \\
\hline
\end{tabular}

Source: Prepared by the researcher using the E-views program based on the study data in Appendix No. (1).

Figure (1) shows that for long-term investment (LINI), the continuous growth of long-term investment during the study period in general versus the continuous decline in general for short-term investment (INSI) is due to the nature of the industry sector that focuses on investing in fixed assets and assets. The true suitability of this sector requires this type of investment as real assets. These findings confirm the explanation in Table (2) for the decrease in short-term investment in industrial companies versus long-term investment. 
Figure (1) : Graph of long-term investment (LINI) and short-term investment(INSI) LINI

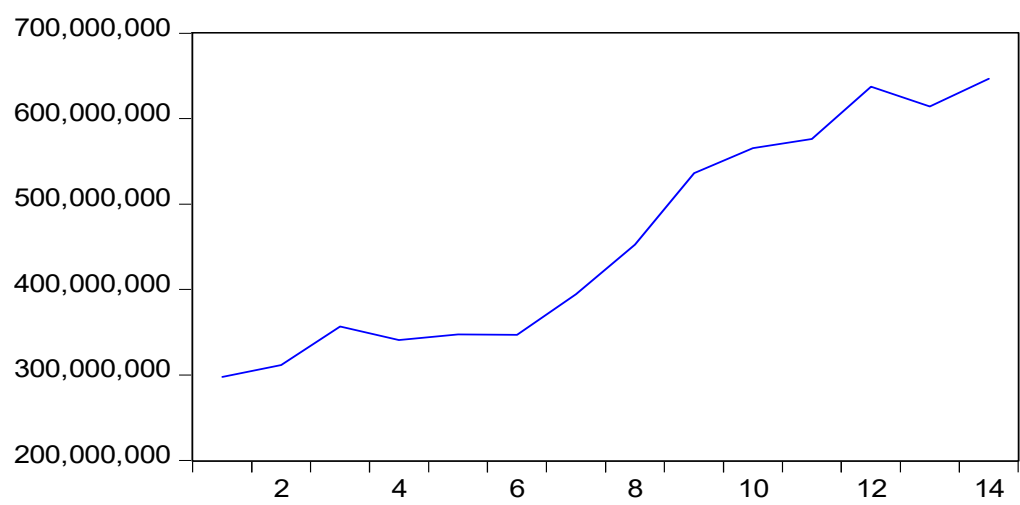

INSI

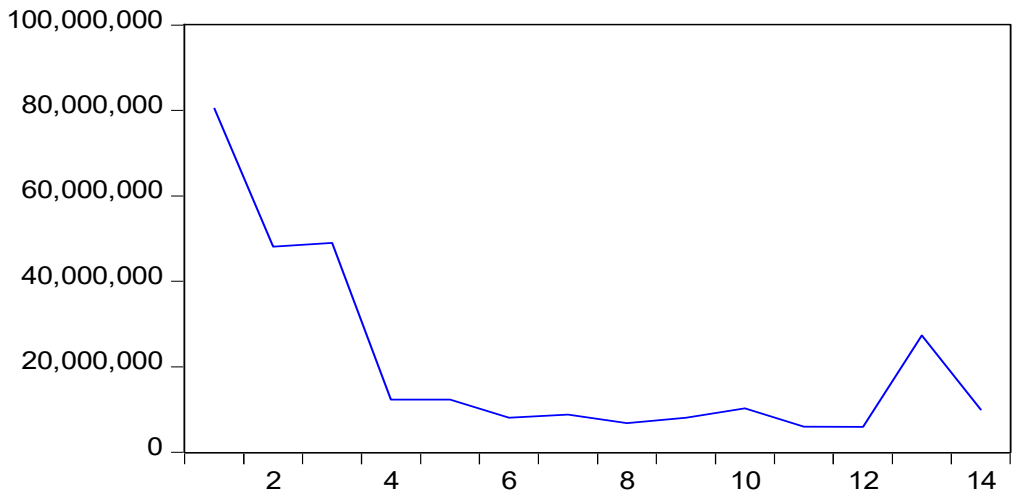

Source: Prepared by the researcher using the E-views program based on the study data in Appendix No. (1)

The figure (1) shows the increase and decrease in return on equity, return on assets, return on shares, and net profit during the study period, where the highest percentage was in 2008 and the lowest percentage was in 2016. However, in general, the trend of return on equity, assets, and return on shares and the net profit of industrial companies is a continuous decline. This finding is a result of the general risks that the industrial sector in Jordan faces, such as inflation and economic recession, as well as special risks such as competition faced by this sector. Thus, new investments are affected by these risks.

Figure (2): Graph of dependent variables
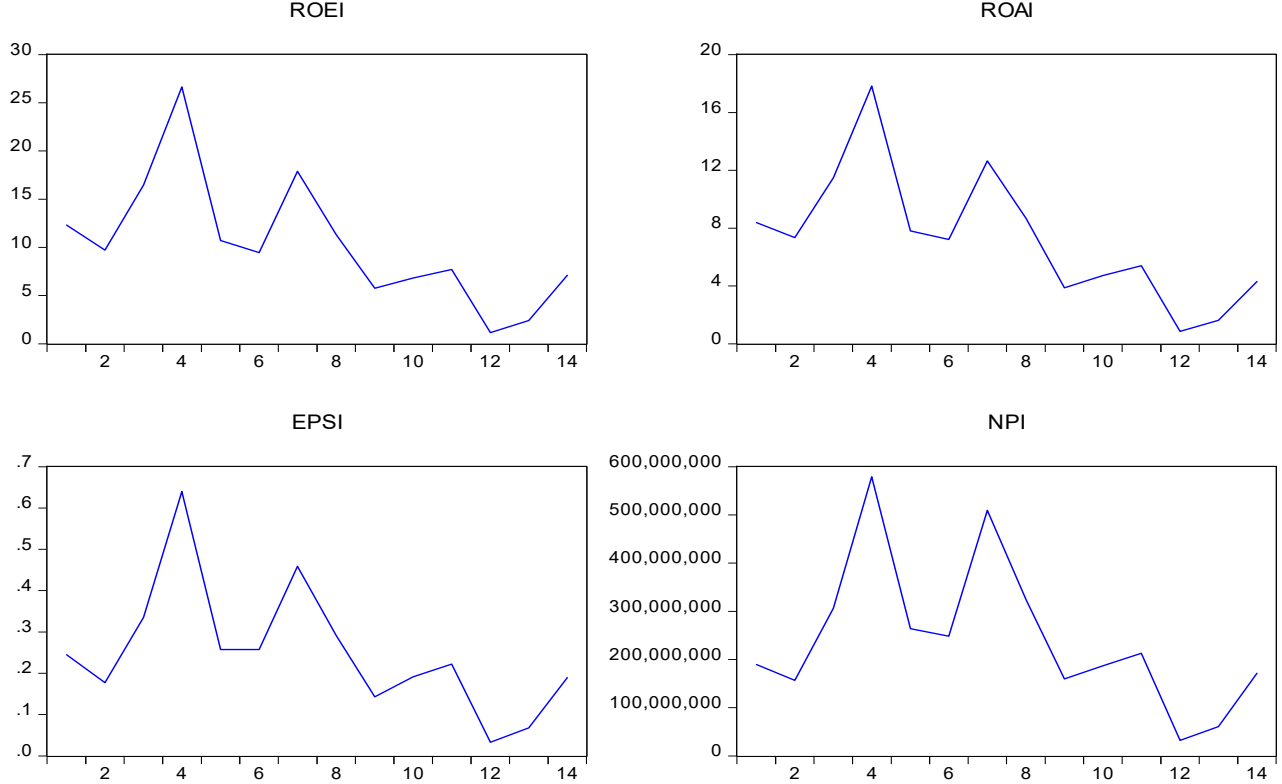

Source: Prepared by the researcher using the E-views program based on the study data in Appendix No. (1). 
Table (3) shows that the simple correlation coefficient is negative between long-term investment, return on assets, return on equity, return on stock and, net profit for industrial companies. Thus, an increase in long-term investment leads to a decrease in the return on assets and return on equity, as well as earnings per share and net profit of industrial companies. The reasons for these findings are general risks to which this sector is exposed, including economic depression, inflation, and informal risks such as competition, the emergence of new products, and management risks. These risks lead to large losses in new investments, especially in the industrial sector, which is considered high-risk compared with other sectors. The correlation analysis also revealed a weak negative relationship between short-term investment, earnings per share, and net profit in the industrial sector due to the small size of short-term investment compared with long-term investment in the industrial sector. This sector depends on long-term investment from purchasing machinery, equipment and building lines new productivity more than reliance on short-term investment. By contrast, the correlation coefficient showed a very weak positive correlation between short-term investment, return on assets, and return on equity.

Table No (3) the simple correlation between the variables of the study

\begin{tabular}{|l|l|l|l|l|}
\hline the simple correlation & ROAI & ROEI & EPSI & NPI \\
\hline LINI & -0.72 & -0.68 & -0.58 & -0.54 \\
\hline INSI & 0.14 & 0.15 & -0.029 & -0.14 \\
\hline
\end{tabular}

Source: Prepared by the researcher using the E-views program based on the study data in Appendix No. (1).

\section{3- Hypotheses testing:}

The study tested the first and second hypotheses from the first model the model was estimated and the results appear as follows.

Table (4): The impact of long-term and short-term investment on equity Independent variable ROEI

\begin{tabular}{|l|l|l|l|}
\hline Variable & Coefficient & t- Statistic & Prob. \\
\hline LINI & $-4.17 \mathrm{E}-08$ & -3.436342 & 0.0056 \\
\hline INSI & $-8.04 \mathrm{E}-08$ & -1.140781 & 0.2782 \\
\hline C & 31.20663 & 4.736594 & 0.0006 \\
\hline
\end{tabular}

Source: Prepared by the researcher using the E-views program based on the study data in Appendix No(1).

R-Squared: $52 \%$

Adjusted R- Squared: 44\%

F-Statistic : $6.1 \quad$ Prob(F-statistic ) : 0.015934

Durbin-Watson stat: 2.14

The following model was built to test the study hypotheses. The model shows the coefficient of determination (modified R squared 52\%), which means that changes in the independent variables explained approximately $\mathbf{5 2 \%}$ of the changes in the dependent variable. The value of F-statistic reaches 6.1, and the significance level is close to zero, which means that the model is statistically significant. The Durbin-Watson coefficient was 2.14, indicating that the model is appropriate and statistically significant, and judging the existence of autocorrelation problem or systematic error is not possible

The researcher also tested the model's ability to predict, as Figure No. (3) indicates the model's ability to predict return on equity.

Figure No. (3) indicates the model's ability to predict return on equity

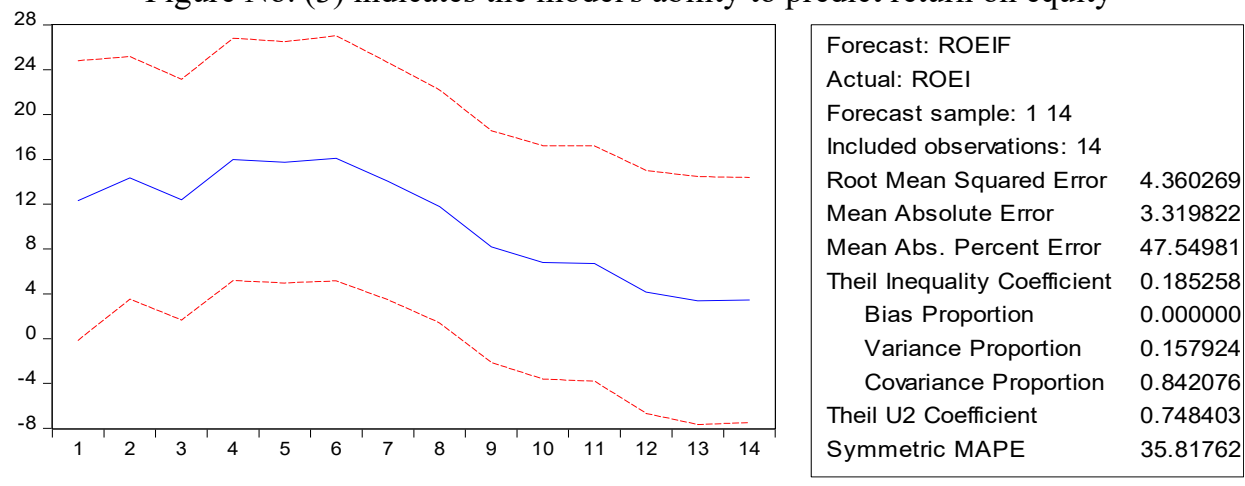

Source prepared by the researcher using the program E-views based on study data in Appendix (1)

\section{1- Autocorrelation teste and Variance test for the first model}

\subsection{1- Autocorrelation teste}

Autocorrelation is tested by the E-views program using the Breusch-Godfrey serial correlation Lagrange multiplier (LM) test to check the problem of autocorrelation in the model Appendix 2 show that the Chi-square 
probability at lags (1) are greater than 5\%, which indicates the absence of the autocorrelation problem in the model. 3.1.2- Variance teste

Variance is tested by the E-views Program using the autoregressive conditional heteroskedasticity test (ARCH) to check the problem of variance in the model Appendix (3) demonstrate that the Chi-square probability at lags (1) are greater than $5 \%$, which indicates the absence of variance instability in the model

Hypothesis 1: No statistically significant positive relationship at $(\alpha \geq 0.05)$ is found between long-term investment and return on equity.

The standard analysis in Table (3) showed that the estimated coefficient to long-term investment is return on equity 1 to $-4.17 \mathrm{E}-08$, which is a negative signal. Thus, the relationship between the change in long-term investment) and the change in (ROEI) is negative. This result was consistent with some studies such as Pu Shen (2005). The possible explanation for this result is that the company expands long-term investment in a way that is not in line with economic conditions, general risks, and private risks, leading to companies bearing the expenses that lead to lower financial performance in industrial companies listed on the Amman Stock Exchange.

According to the T-test, the result is statistically significant at $1 \%$. The confidence level for this variable is equal to $99 \%$. Therefore, the hypothesis is accepted, that is, no a statistically significant positive relationship at ( $\alpha$ $\geq 0.05$ ) the long-term investment and return on equity.

Hypothesis 2: No statistically significant positive relationship at $(\alpha \geq 0.05)$ is found between short-term investment and return on equity.

The standard estimate of the model shows no relationship between the change in short-term investment and the change in the return on equity. This result was consistent with some studies, such as Muhammad Samih Tayfour (2011) and Crispus Ndungu Karanja (2012). A possible explanation for this finding is the nature of the industrial sector by the small size of short-term investment versus the interest in long-term investment in the industrial sector. Therefore, the hypothesis is accepted, that is, no statistically significant positive relationship at $(\alpha 0.05)$ is found between the short-term investment and return on equity

The study tested the third and fourth hypotheses through the second model Where the model was estimated and the results appeared as follows.

Table (5) The impact of investment is long and short term on return on assets Independent variable ROAI

\begin{tabular}{|l|l|l|l|}
\hline Variable & Coefficient & t- Statistic & Prob. \\
\hline LINI & $-2.18 \mathrm{E}-08$ & -2.824801 & 0.0165 \\
\hline INSI & $5.34 \mathrm{E}-08$ & 0.926245 & 0.3742 \\
\hline C & 15.30508 & 3.069198 & 0.0107 \\
\hline
\end{tabular}

Source: Prepared by the researcher using the E-views program based on the study data in Appendix No. (1).

\section{R-Squared: $56 \%$}

Adjusted R- Squared: $48 \%$

F-Statistic: $7.12 \quad$ Prob (F-statistic) 0.010347

Durbin-Watson stat: 1.87

The following model was built to test the study hypotheses. The model shows the coefficient of determination (modified R squared 56\%), which means that changes in the independent variables explained approximately 56\% of the changes in the dependent variable. The value of F-statistic reaches 7.12, and the significance level is close to zero, which means that the model is statistically significant. The Durbin-Watson coefficient was 1.87, indicating that the model is appropriate and statistically significant, and judging the existence of autocorrelation problem or systematic error is not possible

The researcher also tested the model's ability to predict, as Figure No. (4) indicates the model's ability to predict return on asset.

Figure No. (4) indicates the model's ability to predict return on asset.

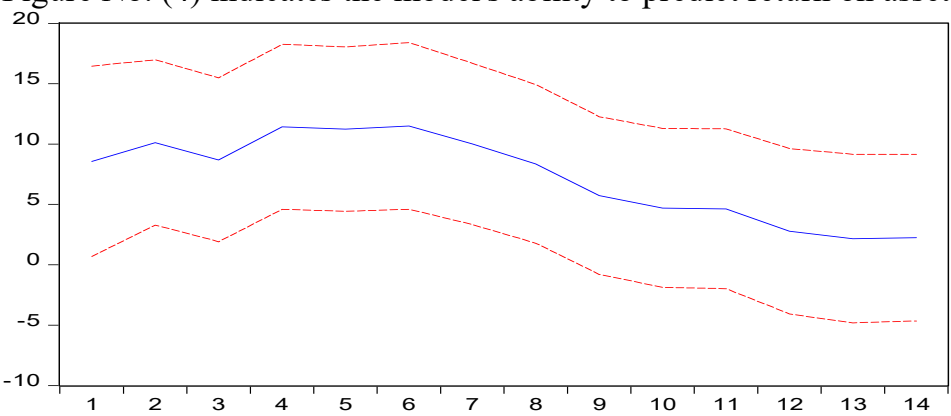

\begin{tabular}{|c|c|}
\hline Forecast: ROAIF & \\
\hline Actual: ROAI & \\
\hline $\begin{array}{l}\text { Forecast sample: } 114 \\
\text { Included observations: } 14\end{array}$ & \\
\hline Root Mean Squared Error & 2.75386 \\
\hline Mean Absolute Error & $2.1432 \varepsilon$ \\
\hline Mean Abs. Percent Error & 42.626 \\
\hline Theil Inequality Coefficient & 0.16666 \\
\hline Bias Proportion & 0.00000 \\
\hline Variance Proportion & 0.12721 \\
\hline Covariance Proportion & $0.8727 \varepsilon$ \\
\hline Theil U2 Coefficient & 0.72238 \\
\hline Symmetric MAPE & 33.3195 \\
\hline
\end{tabular}

Source: Prepared by the researcher using the E-views program based on the study data in Appendix No. (1). 


\subsection{Autocorrelation teste and Variance test for the second model}

\subsection{1- Autocorrelation teste}

Autocorrelation is tested by the E-views program using the Breusch-Godfrey serial correlation Lagrange multiplier (LM) test to check the problem of autocorrelation in the model Appendix 4 show that the Chi-square probability at lags (1) are greater than 5\%, which indicates the absence of the autocorrelation problem in the model. 3.2.2- Variance teste

Variance is tested by the E-views Program using the autoregressive conditional heteroskedasticity test (ARCH) to check the problem of variance in the model Appendix (5) demonstrate that the Chi-square probability at lags (1) are greater than $5 \%$, which indicates the absence of variance instability in the model

Hypothesis 3: No statistically significant positive relationship at $(\alpha \geq 0.05)$ is found between long-term investment and return on assets.

The standard analysis in Table (4) showed that the estimated coefficient to (long-term investment) is return on assets to $-2.18 \mathrm{E}-08$, which is a negative signal and means that the relationship between the change in (long Investment) and the change in (ROAI) is negative. This result was consistent with some studies such as Pu Shen (2005). The possible explanation for this result is that the company expands long-term investment in a way that is not in line with economic conditions, general risks, and private risks, leading to companies bearing the expenses that lead to lower financial performance in industrial companies listed on the Amman Stock Exchange.

According to the T-test, the result is statistically significant at $1 \%$. The confidence level for this variable is equal to $99 \%$. Therefore, the hypothesis is accepted, that is, no a statistically significant positive relationship at ( $\alpha$ $\geq 0.05$ ) the short -term investment and return on assets.

Hypothesis 4: No statistically significant positive relationship at $(\alpha \geq 0.05)$ is found between short-term investment and return on assets.

It was evident from the standard estimate of the model that there is no relationship between the change in shortterm investment and the change in the return on assets, and This result was consistent with some studies, such as Muhammad Samih Tayfour (2011) and Crispus Ndungu Karanja (2012). A possible explanation for this finding is the nature of the industrial sector by the small size of short-term investment versus the interest in long-term investment in the industrial sector. Therefore, the hypothesis is accepted, that is, no statistically significant positive relationship at ( $\alpha 0.05$ ) is found between the short-term investment and return on assets.

The study tested the fifth and sixth hypotheses through the third model Where the model was estimated and the results appeared as follows.

Table: (6) The impact of investment is long and short-term on the earnings per share Dependent variable EPSI

\begin{tabular}{|l|l|l|l|}
\hline Variable & Coefficient & t- Statistic & Prob. \\
\hline LINI & $-4.17 \mathrm{E}-08$ & $-9.65 \mathrm{E}-10$ & 0.0072 \\
\hline INSI & $-8.04 \mathrm{E}-08$ & $-3.09 \mathrm{E}-09$ & 0.0976 \\
\hline C & 31.20663 & 0.758412 & 0.0006 \\
\hline
\end{tabular}

Source: Prepared by the researcher using the E-views program based on the study data in Appendix No. (1).

R-Squared: $\mathbf{5 0 \%}$

Adjusted R- Squared: 40.4\%

F-Statistic : $5.4 \quad$ Prob(F-statistic ) : 0.023

Durbin-Watson stat : 2.3 .

The following model was built to test the study hypotheses. The model shows the coefficient of determination (modified R squared 50\%), which means that changes in the independent variables explained approximately $\mathbf{5 0 \%}$ of the changes in the dependent variable. The value of F-statistic reaches 5.4, and the significance level is close to zero, which means that the model is statistically significant. The Durbin-Watson coefficient was 2.3 , indicating that the model is appropriate and statistically significant, and judging the existence of autocorrelation problem or systematic error is not possible

The researcher also tested the model's ability to predict, as Figure No. (5) indicates the model's ability to predict EPSI. 
Figure No. (5) indicates the model's ability to predict EPSI

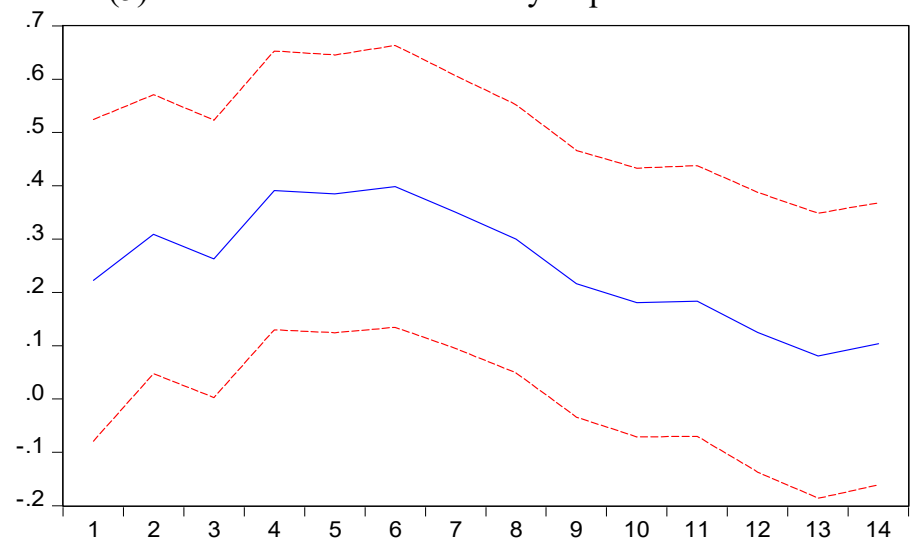

- EPSIF ---- \pm 2 S.E.

\begin{tabular}{ll}
\hline Forecast: EPSIF & \\
Actual: EPSI & \\
Forecast sample: 114 & \\
Included observations: 14 & \\
Root Mean Squared Error & 0.105518 \\
Mean Absolute Error & 0.083914 \\
Mean Abs. Percent Error & 49.23153 \\
Theil Inequality Coefficient & 0.187417 \\
$\quad$ Bias Proportion & 0.000000 \\
\multicolumn{1}{c}{ Variance Proportion } & 0.173535 \\
$\quad$ Covariance Proportion & 0.826465 \\
Theil U2 Coefficient & 0.659876 \\
Symmetric MAPE & 36.19605 \\
\hline
\end{tabular}

Forecast: EPSIF

Included observations: 14

Root Mean Squared Error

0.083914

9.23153

.173535

0.659876

36.19605

Source: Prepared by the researcher using the E-views program based on the study data in Appendix No. (1).

\section{3- Autocorrelation teste and Variance test for the third model}

\subsection{1- Autocorrelation teste}

Autocorrelation is tested by the E-views program using the Breusch-Godfrey serial correlation Lagrange multiplier (LM) test to check the problem of autocorrelation in the model Appendix (6) show that the Chi-square probability at lags (1) are greater than 5\%, which indicates the absence of the autocorrelation problem in the model. 3.3.2- Variance teste

Variance is tested by the E-views Program using the autoregressive conditional heteroskedasticity test (ARCH) to check the problem of variance in the model Appendix (7) demonstrate that the Chi-square probability at lags (1) are greater than $5 \%$, which indicates the absence of variance instability in the model

Hypothesis 5: No statistically significant positive relationship at $(\alpha \geq 0.05)$ is found between long-term investment and earnings per share.

The standard analysis in Table (6) showed that the estimated coefficient to (long-term investment) is $-4.17 \mathrm{E}-08$, which is a negative signal. Thus, the relationship between the change in (long-term investment) and the change in (EPSI) is negative. This result was consistent with some studies such as Pu Shen (2005). A possible explanation for this result is that the company is expanding long-term investment in a manner inconsistent with economic conditions, general risks, and private risks, leading leads to companies bearing operational expenses that lead to a reduction in the financial performance of the industrial companies listed on the Amman Stock Exchange. Furthermore, the company's expansion in investment results in financing as regards the methods of underwriting for new shares that lead to a reduction in the return on one share. The reason for this finding is that the return per share is the net profit attributable to the shareholders over the number of shares subscribed, and the relationship is inverse between the return on the share and the number of shares subscribed.

According to the T-test, the result is statistically significant at $1 \%$. The confidence level for this variable is equal to $99 \%$. Therefore, the hypothesis is accepted, that is, no a statistically significant positive relationship at ( $\alpha$ 0.05 ) the long -term investment and earnings per share.

Hypothesis 6: No statistically significant positive relationship at $(\alpha \geq 0.05)$ is found between short-term investment and earnings per share.

The standard estimate of the model showed that the relationship between the change in short-term investment and the change in return on share is negative but weak because the estimated coefficient of the short-term investment impact was $(-8.04 \mathrm{E}-08)$ With probability with probability $(0.09)$. In other words, the negative relationship between the effect of short-term investment on the change in EPS.

This result was consistent with some studies such as Abdkader Ahmad Hussen (2017), which showed a negative relationship between investment in government securities and financial performance (return on assets). A possible explanation for this finding is that the return on the share is the net profit attributable to the shareholders on the number of shares subscribed. An additional explanation is the inverse relationship between the return on the share and the number of shares subscribed because the industrial companies are expanding long-term investment through subscribing to shares, leading to a decrease in the return per share because companies also achieve losses in long-term investment also because of the economic conditions that led to a decrease in the earnings per share.

According to the T-test, the result is statistically significant at $1 \%$. The confidence level for this variable is equal to $99 \%$. Therefore, the hypothesis is accepted, that is, no a statistically significant positive relationship at $(\alpha \geq 0.05)$ the short -term investment and earnings per share. 
The study tested the seventh and eighth hypotheses through the third model Where the model was estimated and the results appeared as follows.

Table (7) the impact of Long-term and short-term investment on net profit after tax

\begin{tabular}{|l|l|l|l|}
\hline Variable & Coefficient & t- Statistic & Prob. \\
\hline LINI & -0.972378 & -3.522235 & 0.0048 \\
\hline INSI & -3.868092 & -2.411178 & 0.0345 \\
\hline C & $7.70 \mathrm{E}+08$ & 5.139378 & 0.0003 \\
\hline
\end{tabular}

Source: Prepared by the researcher using the E-views program based on the study data in Appendix No. (1).

R-Squared: $53 \%$

Adjusted R- Squared: $45.4 \%$

F-Statistic : 6.4 Prob(F-statistic ) : $0.014041 \quad$ Durbin-Watson stat : 2.35 .

The following model was built to test the study hypotheses. The model shows the coefficient of determination (modified R squared 53\%), which means that changes in the independent variables explained approximately 53\% of the changes in the dependent variable. The value of F-statistic reaches $\mathbf{6 . 4}$, and the significance level is close to zero, which means that the model is statistically significant. The Durbin-Watson coefficient was 2.35 , indicating that the model is appropriate and statistically significant, and judging the existence of autocorrelation problem or systematic error is not possible

The researcher also tested the model's ability to predict, as Figure No. (6) indicates the model's ability to predict net profit after tax.

Figure No. (6) indicates the model's ability to predict net profit after tax

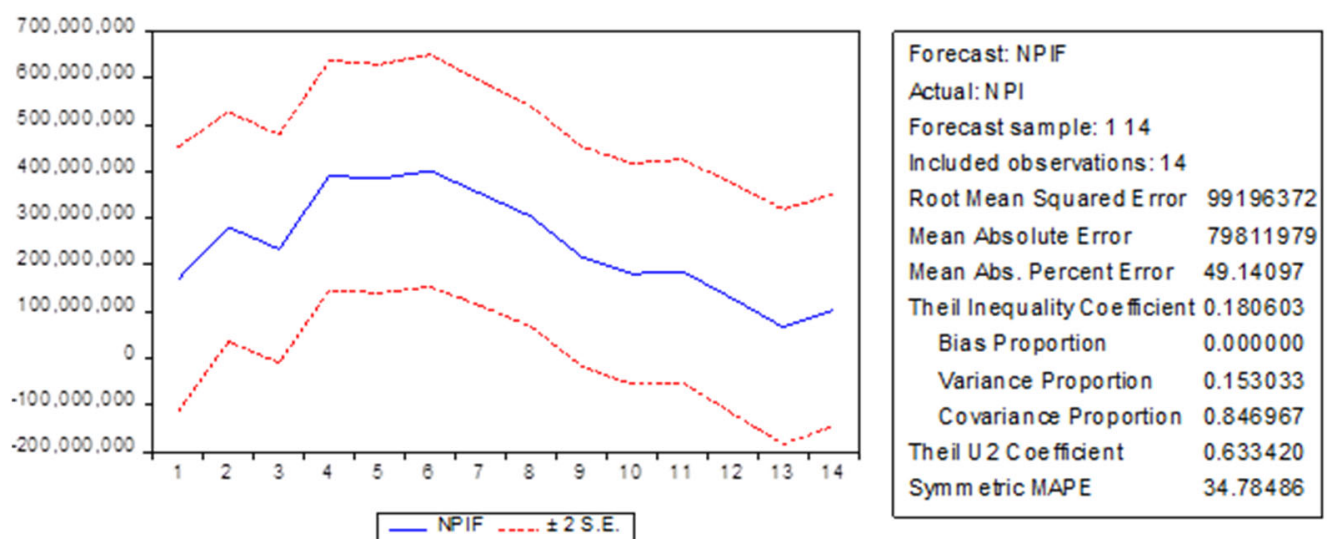

Source: Prepared by the researcher using the E-views program based on the study data in Appendix No. (1).

\section{4- Autocorrelation teste and Variance test for the fourth model}

\subsection{1- Autocorrelation teste}

Autocorrelation is tested by the E-views program using the Breusch-Godfrey serial correlation Lagrange multiplier (LM) test to check the problem of autocorrelation in the model Appendix (8) show that the Chi-square probability at lags (1) are greater than 5\%, which indicates the absence of the autocorrelation problem in the model. 3.4.2- Variance teste

Variance is tested by the E-views Program using the autoregressive conditional heteroskedasticity test (ARCH) to check the problem of variance in the model Appendix (9) demonstrate that the Chi-square probability at lags (1) are greater than $5 \%$, which indicates the absence of variance instability in the model

Hypothesis 7: No statistically significant positive relationship at $(\alpha \geq 0.05)$ is found between long-term investment and net profit after tax.

The standard analysis in Table (5) showed that the estimated coefficient to (long-term investment) is -4.17E-08, which is a negative signal and means that the relationship between the change in (long -Investment) and the change in net profit after tax is negative. This result was consistent with some studies such as Pu Shen (2005). The possible explanation for this result is that the company expands long-term investment in a way that is not in line with economic conditions, general risks, and private risks, leading to companies bearing the expenses that lead to lower financial performance in industrial companies listed on the Amman Stock Exchange.

According to the T-test, the result is statistically significant at $1 \%$. The confidence level for this variable is equal to $99 \%$. Therefore, the hypothesis is accepted, that is, no a statistically significant positive relationship at ( $\alpha$ 0.05 ) the long -term investment and net profit after tax.

Hypothesis 8 : No statistically significant positive relationship at $(\alpha \geq 0.05)$ is found between short-term investment and net profit after tax. 
It was found from the standard estimate of the model that the relationship between the change in short-term investment and the change in net profit after tax is negative but weak as the estimated coefficient of the short-term investment impact was (-8.04E-08), that is, the negative relationship between the impact of short-term investment on the change In NPI

This result was consistent with some studies, such as Abdkader ahmad Hussen, 2017. which showed a negative relationship between investment in government securities and financial performance. A possible explanation for this finding is the nature of the industrial sector by the small size of short-term investment versus the interest in long-term investment in the industrial sector.

According to the T-test, the result is statistically significant at $1 \%$. The confidence level for this variable is equal to $99 \%$. Therefore, the hypothesis is accepted, that is, no a statistically significant positive relationship at $(\alpha \geq 0.05)$ the short -term investment and net profit after tax..

The results of the study can also be strengthened by the negative relationship between long-term investment and fixed assets turnover in industrial companies listed on the Amman Financial Market because the correlation coefficient between long-term investment and fixed assets turnover was -33 during the study period. This finding indicates the low efficiency of fixed assets in Increased revenue.

The results of the study can be explained by the fact that investors are optimistic and expand in new investments. However, the volume of demand is not as expected, leading to a decrease in companies' sales and additional operating costs, resulting in declines in the financial performance of industrial companies. This finding is identical to the theory of over-investment, which was proposed by Clark and Harrod and is mentioned in the theoretical part of the present study.

\section{5 - Johansen Co-integration Test.}

The study attempts to conduct the Johansson test for co-integration in the long run. One of the conditions for the co-integration test is that the time series be stable at the same level. Thus, the stability of the variables of each model will be tested through the Philips Perron test-pp. This test is one of the best tests in measuring the stability of time series (Dalia Musa Al-Sayrafi,2017, pp112-115). The analysis is as follows.

Appendices (10-13) show the Philips Perron test, which shows the results of the unit root test for the remainder. The variables of the models are stable at the level, that is, they are static in their original form. Here, the study can deal with the variables in their original form where the static analysis shows the root of unity that all the study models are static at the 5\% level.

To perform the co-integration, the researcher tested the deceleration periods for the study variables. Appendix (14) shows that the slowdown period for the study variables is (1).

The study variables will be dealt with in their original form and the lag periods (lag1) to perform the cointegration.

Accordingly, a co-integration has been conducted for all the study models, as is evident from Appendices (15-18). In each model, the number of vectors of co-integration $=2$.

\section{4- Results and Recommendations.}

\section{1- Results}

A negative relationship with a statistical significance at the 5\% level is found between long-term investment, return on equity, and return on industrial company assets listed on the Amman Stock Exchange because a long-term investment in the industrial sector is exposed to general risks such as economic depression and inflation, as well as company risks, especially competition. Investment in the industrial sector requires high operating costs that lead to lower profits, especially in cases where the company faces common risks such as operating risks and financial risks.

No statistically significant relationship at the 5\% level was found between short-term investment, return on equity, and return on assets for the industrial company listed on the Amman Stock Exchange. The reason for this finding is the small size of short-term investment versus long-term investment, especially in industrial firms interested in long-term investment at the expense of short-term investment.

A negative statistically significant relationship at the 5\% level was found between long-term investment, earnings per share and net profit after tax for industrial companies listed in the Amman Financial Market due to the high operational costs of long-term investment and the fact that the return per share is affected by the number of shares subscribed. Industrial companies finance investment through subscribing to shares that lead to a decrease in the return per share, especially in cases of economic depression that lead to a decrease in sales, new investments, and consequently a decrease in profits and a return per share.

A negative relationship of weak statistical significance is found between short-term investment and stock return. Furthermore, a negative relationship with statistical significance at the $5 \%$ level is found between shortterm investment and net profit after tax for industrial companies listed on the Amman Financial Market. The reason for this finding is the lack of interest of industrial companies to invest short-term versus long-term, especially in 
this sector. In addition, speculation in the financial market through stocks affects the financial performance of companies.

The co-integration test of all study models indicates that a long-term equilibrium relationship between these variables means that the variables do not diverge from one another and exhibit similar behavior in the long run.

\section{2- Recommendations}

On the basis of the results, the following recommendations can be reached.

The people responsible for investment decisions in the industrial companies in Jordan must conduct feasibility studies for the proposed investment projects and consider the effect of new investments on the profitability of the companies. Furthermore, investment managers in industrial companies in Jordan should focus on establishing new projects that do not suffer from economic depression by examining the local, regional, and international markets and finding new projects that are compatible with them. They should also consider global entanglement. Industrial companies and investment managers in industrial companies should not commit to short-term investments in the financial markets because they lead to losses in industrial companies and, thus, a decrease in financial performance. Other recommended initiatives include producing new products that achieve a competitive advantage in the same investment field and adopting the price determination decision by considering the consumer's ability to buy and income. Practitioners should work to find diversity in new investments and production lines that consider the economic conditions of the target community so that diversification of high-, medium-, and low-quality products can be achieved to suit the consumer's income.

\section{5- References}

- $\quad$ Anas, A,Q \& Mohammad, A, M, A. (2015). The Relationship between the Investment in Current Assets and Profitability \& Liquidity. Journal of Finance and Investment Analysis, vol. 4, no. 4, 2015, pp11-22

- $\quad$ Abdkader,A, H . (2017).the relationship between investment and financial performance of commercial banks in keney, research project of master ,university of Nairobi. online:http://erepository.uonbi.ac.ke/bitstream/handle/11295/102735/FUAD0723\%20EDITED.pdf?sequenc $\mathrm{e}=1$ \&isAllowed $=\mathrm{y}$

- $\quad$ Almas H, H,L ,2008, Investment and corporate performance of firms: correlation or causation? Corporate Ownership \& Control , 6( 2).

- $\quad$ Baciu \& Brezeanu P.(2018). Impact of Financial Structure on Return on Equity: Evidence from the Wholesale motor vehicle Parts and Accessories Industry, Eurasian Journal of Economics and Finance, 6(4), 2018, pp $38-47$.

- $\quad$ Chashmi NA \& Fadaee ,M.(2016). Impact of Financial Performance and Growth Opportunities on Success or Failure of Companies: Evidence from Tehran Stock Exchange, Journal of Accounting \& Marketing, 5(2) PP 1-4 online http://erepository.uonbi.ac.ke/bitstream/handle

- Crispus N, k. (2012). The relationship between investment decisions and financial performance of small and medium scale enterprises in Limuru town, Kenya, a research project Submitted in the Partial Fulfillment of the Requirements for the award of Degree in masters of Business Administration, University of Nairobi, October, pp. 1-64

- Dalia ,M, ,S.(2017). The impact of the services sector on the industrial sector and economic growth in Palestine 2000-2016, Master Thesis, Faculty of Commerce, Islamic University, Gaza. Pp112-115.

- Hasan, S, H, H, A, .(2019). The Impact of Corporate Investment Behaviour on the Corporate Performance: Evidence from an Emerging Market, journal of Management Information and Decision Sciences, 22(1) online https://www.abacademies.org/articles/the-impact-of-corporate-investment-behaviour-on-the-corporateperformance-evidence-from-an-emerging-market-7800.html

- Hadi, S.(2019) The Impact of Investment Decision and Funding on Financial Performance and Firm Value, Jurnal Ekonomi Bisnis dan Kewirausahaan,8(2), pp 103-112 . online file://C:/Users/LENOVO/Downloads/hadiJEBIK.pdf

- Geoff ,W.(2014), Long-Term Investing: What Determines Investment Horizon? Research Working Paper, center for international finance and regulation See discussions, stats, and author profiles for this publication at: https://www.researchgate.net/publication/26256131

- Martijn, C, A, P, and Z,S.(2017). Short-Term Investors, Long-Term Investments, and Firm Value, Online https://ecgi.global/sites/default/files/2. short-term_investors_2. long-

term investments and firm value.pdf

- $\quad$ Muhammad, S, T. (2011). The Impact of Capital Expenditure on Financial and Operational Performance in Jordanian Pharmaceutical Industry Companies, Master Thesis, College of Business, Middle East University.

- $\quad$ Peter Weil, 1992, The Relationship between Investment in information technology and firm Performance: A Study of the Valve Manufacturing Sector, Center for Information Systems, Research Sloan School of Management Massachusetts Institute of Technology .pp1-51. online 
file://C:/Users/LENOVO/Downloads/The_Relationship_Between_Investment_in_Information\%20(1).pdf

- $\quad$ Pu Shen, How Long Is a Long-Term Investment,2005, economic review, at the Federal Reserve Bank of Kansas City. On line https://www.kansascityfed.org/publicat/econrev/pdf/1q05shen.pdf

- $\quad$ Shogiri ,N, M \& et al.(2016). Investment Management, 1st Edition, Dar Al Masirah for Publishing, Distribution and Printing, Amman, Jordan, pp112-115.

\section{Website}

- Abdul,J, S, The Financial Mother in the Eyes of an Islamic Economics Student, online https://alsabhany.com/index.php/articles/financial-crisis.

- Amman Financial Market, Companies Directory, Consolidated Financial Statements online https://www.ase.com.jo/ar/history?history_category=65,

- $\quad$ https://www.ase.com.jo/ar/history?history_category $=64$

\section{6- Appendices}

Appendix (1): variables data of study

$\begin{array}{lrrrrrrr} & \text { LINI } & \text { INSI } & \text { ROEl } & \text { ROAl } & \text { EPSI } & \text { NPI } \\ 1 & 297601929 & 80474241 & 12.3047266 \ldots & 8.37948779 \ldots & 0.24499778 \ldots & 189698616 \\ 2 & 311519212 & 48118205 & 9.70589318 \ldots & 7.33925514 \ldots & 0.17763000 \ldots & 157005136 \\ 3 & 356788199 & 48973067 & 16.4706006 \ldots & 11.4758022 \ldots & 0.33504061 \ldots & 306337873 \\ 4 & 340958206 & 12357988 & 26.6347771 \ldots & 17.8267050 \ldots & 0.63986624 \ldots & 578996005 \\ 5 & 347475633 & 12302378 & 10.6903920 \ldots & 7.79880908 \ldots & 0.25726984 \ldots & 263997906 \\ 6 & 346994197 & 8027319 & 9.45505019 \ldots & 7.20722767 \ldots & 0.25726984 \ldots & 248138410 \\ 7 & 394562280 & 8803159 & 17.8925802 \ldots & 12.6479478 \ldots & 0.45846969 \ldots & 509896896 \\ 8 & 452755617 & 6795238 & 11.3166104 \ldots & 8.66120833 \ldots & 0.29106372 \ldots & 324303344 \\ 9 & 536276690 & 8031231 & 5.75180849 \ldots & 3.86089325 \ldots & 0.14313145 \ldots & 159594791 \\ 10 & 565581464 & 10255357 & 6.80988179 \ldots & 4.70757654 \ldots & 0.19137467 \ldots & 186612712 \\ 11 & 576388256 & 5973288 & 7.69557345 \ldots & 5.39298611 \ldots & 0.22250010 \ldots & 212813419 \\ 12 & 637409908 & 5905241 & 1.14932900 \ldots & 0.85398245 \ldots & 0.03326751 \ldots & 32311523 \\ 13 & 614364932 & 27365934 & 2.39209950 \ldots & 1.61727802 \ldots & 0.06759846 \ldots & 60828629 \\ 14 & 646731195 & 9954546 & 7.09048232 \ldots & 4.30650725 \ldots & 0.18945600 \ldots & 171430011\end{array}$

Source:https://www.ase.com.jo/ar/history?history_category $=64$

Appendix (2): Autocorrelation teste of model (1)

Breusch-Godfrey Serial Correlation LM Test:

\begin{tabular}{llll}
\hline \hline F-statistic & 0.086271 & Prob. F(1,10) & 0.7750 \\
Obs*R-squared & 0.119747 & Prob. Chi-Square(1) & 0.7293 \\
\hline \hline
\end{tabular}

Source: The E-views program based on the study data in Appendix No. (1).

Appendix (3): Variance teste of model (1)

Heteroskedasticity Test: ARCH

\begin{tabular}{lllr}
\hline \hline F-statistic & 0.716248 & Prob. F(1,11) & 0.4154 \\
Obs*R-squared & 0.794727 & Prob. Chi-Square(1) & 0.3727 \\
\hline \hline
\end{tabular}

Source: The E-views program based on the study data in Appendix No. (1). 
Appendix (4) Autocorrelation teste of model (2)

Breusch-Godfrey Serial Correlation LM Test:

\begin{tabular}{lllr}
\hline \hline F-statistic & 0.104644 & Prob. F(1,10) & 0.7530 \\
Obs*R-squared & 0.144984 & Prob. Chi-Square(1) & 0.7034
\end{tabular}

Source: The E-views program based on the study data in Appendix No. (1).

Appendix (5): Variance teste of model (2)

Heteroskedasticity Test: ARCH

\begin{tabular}{llll}
\hline \hline F-statistic & 0.264804 & Prob. F(1,11) & 0.6170 \\
Obs*R-squared & 0.305593 & Prob. Chi-Square(1) & 0.5804 \\
\hline \hline
\end{tabular}

Source: The E-views program based on the study data in Appendix No. (1).

Appendix (6): Appendix (4) Autocorrelation teste of model (3)

Breusch-Godfrey Serial Correlation LM Test:

\begin{tabular}{lllr}
\hline F-statistic & 0.367373 & Prob. F(1,10) & 0.5579 \\
Obs*R-squared & 0.496097 & Prob. Chi-Square(1) & 0.4812 \\
\hline \hline
\end{tabular}

Source: The E-views program based on the study data in Appendix No. (1).

Appendix (7): Variance teste of model (3)

Heteroskedasticity Test: ARCH

\begin{tabular}{lllr}
\hline \hline F-statistic & 0.056002 & Prob. F(1,11) & 0.8173 \\
Obs*R-squared & 0.065850 & Prob. Chi-Square(1) & 0.7975 \\
\hline
\end{tabular}

Source: The E-views program based on the study data in Appendix No. (1).

Appendix (8) Autocorrelation teste of model (4)

Breusch-Godfrey Serial Correlation LM Test:

\begin{tabular}{llll}
\hline \hline F-statistic & 0.430321 & Prob. F(1,10) & 0.5266 \\
Obs*R-squared & 0.577594 & Prob. Chi-Square(1) & 0.4473 \\
\hline \hline
\end{tabular}

Source: The E-views program based on the study data in Appendix No. (1).

Appendix (9): Variance teste of model (4)

Heteroskedasticity Test: ARCH

\begin{tabular}{llll}
\hline \hline F-statistic & 0.493516 & Prob. F(1,11) & 0.4970 \\
Obs*R-squared & 0.558203 & Prob. Chi-Square(1) & 0.4550 \\
\hline \hline
\end{tabular}


Appendix (10): the Philips Perron test-pp of model (1)

Null Hypothesis: Unit root (individual unit root process)

Series: LINI, INSI, ROEI

Date: 11/27/20 Time: 09:00

Sample: 114

Exogenous variables: Individual effects

Newey-West automatic bandwidth selection and Bartlett kernel

Total (balanced) observations: 39

Cross-sections included: 3

\begin{tabular}{lcc}
\hline \hline Method & Statistic & Prob.** \\
\hline PP - Fisher Chi-square & 27.9817 & 0.0001 \\
PP - Choi Z-stat & -2.09874 & 0.0179 \\
\hline \hline
\end{tabular}

** Probabilities for Fisher tests are computed using an asymptotic Chi-square distribution. All other tests assume asymptotic normality.

Source: The E-views program based on the study data in Appendix No. (1).

Appendix (11): the Philips Perron test-pp of model (2)

Null Hypothesis: Unit root (individual unit root process)

Series: LINI, INSI, ROAI

Date: 11/27/20 Time: 08:53

Sample: 114

Exogenous variables: Individual effects

Newey-West automatic bandwidth selection and Bartlett kernel

Total (balanced) observations: 39

Cross-sections included: 3

\begin{tabular}{lcc}
\hline \hline Method & Statistic & Prob.** \\
\hline PP - Fisher Chi-square & 27.4634 & 0.0001 \\
PP - Choi Z-stat & -1.97038 & 0.0244 \\
\hline \hline
\end{tabular}

** Probabilities for Fisher tests are computed using an asymptotic Chi-square distribution. All other tests assume asymptotic normality.

Source: The E-views program based on the study data in Appendix No. (1).

Appendix (12): the Philips Perron test-pp of model (3)

Null Hypothesis: Unit root (individual unit root process)

Series: LINI, INSI, EPSI

Date: 11/27/20 Time: 09:02

Sample: 114

Exogenous variables: Individual effects

Newey-West automatic bandwidth selection and Bartlett kernel

Total (balanced) observations: 39

Cross-sections included: 3

\begin{tabular}{lcc}
\hline \hline Method & Statistic & Prob.** \\
\hline PP - Fisher Chi-square & 28.9644 & 0.0001 \\
PP - Choi Z-stat & -2.30358 & 0.0106 \\
\hline \hline
\end{tabular}

** Probabilities for Fisher tests are computed using an asymptotic Chi-square distribution. All other tests assume asymptotic normality.

Source: The E-views program based on the study data in Appendix No. (1). 
Appendix (13): the Philips Perron test-pp of model (4)

Null Hypothesis: Unit root (individual unit root process)

Series: LINI, INSI, NPI

Date: 11/27/20 Time: 09:03

Sample: 114

Exogenous variables: Individual effects

Newey-West automatic bandwidth selection and Bartlett kernel

Total (balanced) observations: 39

Cross-sections included: 3

\begin{tabular}{lcc}
\hline \hline Method & Statistic & Prob.** \\
\hline PP - Fisher Chi-square & 28.7092 & 0.0001 \\
PP - Choi Z-stat & -2.25415 & 0.0121 \\
\hline \hline
\end{tabular}

** Probabilities for Fisher tests are computed using an asymptotic Chi-square distribution. All other tests assume asymptotic normality.

Source: The E-views program based on the study data in Appendix No. (1).

\section{Appendix 14: the deceleration periods for the study variables}

VAR Lag Order Selection Criteria

Endogenous variables: LINI INSI ROEI ROAI EPSI NPI

Exogenous variables: $\mathrm{C}$

Date: 11/28/20 Time: 09:07

Sample: 114

Included observations: 13

\begin{tabular}{ccccccc}
\hline \hline Lag & LogL & LR & FPE & AIC & SC & HQ \\
\hline \hline 0 & -726.7309 & NA & $3.66 \mathrm{e}+41$ & 112.7278 & 112.9886 & 112.6742 \\
1 & -634.9074 & $84.76015^{*}$ & $1.46 \mathrm{e}+38^{*}$ & $104.1396^{*}$ & $105.9648^{*}$ & $103.7644^{*}$ \\
\hline \hline
\end{tabular}

* indicates lag order selected by the criterion

LR: sequential modified LR test statistic (each test at 5\% level)

FPE: Final prediction error

AIC: Akaike information criterion

SC: Schwarz information criterion

HQ: Hannan-Quinn information criterion

Source: The E-views program based on the study data in Appendix No. (1). 
Appendix (15) Johansen Co-integration Test of model (1)

Date: 11/27/20 Time: 09:07

Sample (adjusted): 314

Included observations: 12 after adjustments

Trend assumption: Linear deterministic trend

Series: LINI INSI ROEI

Lags interval (in first differences): 1 to 1

Unrestricted Cointegration Rank Test (Trace)

\begin{tabular}{ccccc}
\hline \hline $\begin{array}{c}\text { Hypothesized } \\
\text { No. of CE(s) }\end{array}$ & Eigenvalue & $\begin{array}{c}\text { Trace } \\
\text { Statistic }\end{array}$ & Critical Value & Prob. ${ }^{* *}$ \\
\hline \hline None ${ }^{*}$ & 0.970650 & 65.31278 & 29.79707 & 0.0000 \\
At most 1 & 0.835247 & 22.97107 & 15.49471 & 0.0031 \\
At most 2 & 0.105013 & 1.331351 & 3.841466 & 0.2486 \\
\hline \hline
\end{tabular}

Trace test indicates 2 cointegrating eqn(s) at the 0.05 level

* denotes rejection of the hypothesis at the 0.05 level

**MacKinnon-Haug-Michelis (1999) p-values

Source: The E-views program based on the study data in Appendix No. (1).

\section{Appendix (16) Johansen Co-integration Test of model (2)}

Date: 11/27/20 Time: 09:08

Sample (adjusted): 314

Included observations: 12 after adjustments

Trend assumption: Linear deterministic trend

Series: LINI INSI ROAI

Lags interval (in first differences): 1 to 1

Unrestricted Cointegration Rank Test (Trace)

\begin{tabular}{ccccc}
\hline \hline $\begin{array}{c}\text { Hypothesized } \\
\text { No. of CE(s) }\end{array}$ & Eigenvalue & $\begin{array}{c}\text { Trace } \\
\text { Statistic }\end{array}$ & $\begin{array}{c}0.05 \\
\text { Critical Value }\end{array}$ & Prob.** \\
\hline \hline None * & 0.977798 & 67.70210 & 29.79707 & 0.0000 \\
At most $1 *$ & 0.823147 & 22.01145 & 15.49471 & 0.0045 \\
At most 2 & 0.096838 & 1.222234 & 3.841466 & 0.2689 \\
\hline \hline
\end{tabular}

Trace test indicates 2 cointegrating eqn(s) at the 0.05 level

$*$ denotes rejection of the hypothesis at the 0.05 level

**MacKinnon-Haug-Michelis (1999) p-values

Source: The E-views program based on the study data in Appendix No. (1). 
Appendix (17) Johansen Co-integration Test of model (3)

Date: 11/27/20 Time: 09:06

Sample (adjusted): 314

Included observations: 12 after adjustments

Trend assumption: Linear deterministic trend

Series: LINI INSI EPSI

Lags interval (in first differences): 1 to 1

Unrestricted Cointegration Rank Test (Trace)

Hypothesized

No. of CE(s)
0.05

Statistic

Prob.**

\begin{tabular}{|c|c|c|c|c|}
\hline None * & 0.977842 & 68.12303 & 29.79707 & 0.0000 \\
\hline At most $1 *$ & 0.831022 & 22.40828 & 15.49471 & 0.0039 \\
\hline At most 2 & 0.085492 & 1.072433 & 3.841466 & 0.3004 \\
\hline
\end{tabular}

Trace test indicates 2 cointegrating eqn(s) at the 0.05 level

* denotes rejection of the hypothesis at the 0.05 level

**MacKinnon-Haug-Michelis (1999) p-values

Source: The E-views program based on the study data in Appendix No. (1).

\section{Appendix (18) Johansen Co-integration Test of model (4)}

Date: 11/27/20 Time: 09:04

Sample (adjusted): 314

Included observations: 12 after adjustments

Trend assumption: Linear deterministic trend

Series: LINI INSI NPI

Lags interval (in first differences): 1 to 1

\begin{tabular}{|c|c|c|c|c|}
\hline \multicolumn{5}{|c|}{ Unrestricted Cointegration Rank Test (Trace) } \\
\hline $\begin{array}{l}\text { Hypothesized } \\
\text { No. of CE(s) }\end{array}$ & Eigenvalue & $\begin{array}{c}\text { Trace } \\
\text { Statistic }\end{array}$ & $\begin{array}{c}0.05 \\
\text { Critical Value }\end{array}$ & Prob.** \\
\hline None * & 0.949721 & 55.33474 & 29.79707 & 0.0000 \\
\hline At most $1 *$ & 0.789140 & 19.45264 & 15.49471 & 0.0120 \\
\hline At most 2 & 0.062456 & 0.773903 & 3.841466 & 0.3790 \\
\hline
\end{tabular}

Trace test indicates 2 cointegrating eqn(s) at the 0.05 level

* denotes rejection of the hypothesis at the 0.05 level

**MacKinnon-Haug-Michelis (1999) p-values

Source: The E-views program based on the study data in Appendix No. (1). 